\title{
Abstract \\ Ultra-Wideband Localization of Pulmonary Nodules during Thoracoscopic Surgery ${ }^{+}$
}

\author{
Alberto Battistel (1D and Knut Möller* \\ Institute of Technical Medicine, Furtwangen University, Campus Villingen-Schwenningen \\ Jakob-Kienzle-Straße 17, 78054 VS-Schwenningen, Germany; alberto.battistel@hs-furtwangen.de \\ * Correspondence: Knut.Moeller@hs-furtwangen.de \\ + Presented at the 8th International Symposium on Sensor Science, 17-28 May 2021; Available online: \\ https://i3s2021dresden.sciforum.net/.
}

check for

updates

Citation: Battistel, A.; Möller, K. Ultra-Wideband Localization of Pulmonary Nodules during Thoracoscopic Surgery. Eng. Proc. 2021, 6, 4. https://doi.org/10.3390/ I3S2021Dresden-10095

Academic Editors: Gianaurelio

Cuniberti and Larysa Baraban

Published: 17 May 2021

Publisher's Note: MDPI stays neutral with regard to jurisdictional claims in published maps and institutional affiliations.

Copyright: (C) 2021 by the authors. Licensee MDPI, Basel, Switzerland. This article is an open access article distributed under the terms and conditions of the Creative Commons Attribution (CC BY) license (https:/ / creativecommons.org/licenses/by/ $4.0 /)$.

\begin{abstract}
Lung cancer is one of the most common causes of cancer-related death worldwide. It is usually detected by CT or MRI and removed through thoracoscopic surgery. However, during surgery, the lung collapses, and a new determination of the position of the pulmonary nodule is necessary, which is particularly challenging in the case of minimally invasive surgeries when palpation is not possible. In this contribution, ultra-wideband (UWB) radio technology, which employs a short burst of high-frequency electromagnetic waves, is studied to localize the pulmonary nodule. In short, an antenna in close proximity with the lung surface produces a signal, and the echo emanating from discontinuities in the lung tissue, i.e., the pulmonary nodule, can be used for the localization. A similar approach has already been proposed for breast cancer. Simulations were used to explore the relationship between frequency range and penetration depth and showed that shallow nodules, below $2 \mathrm{~cm}$ in depth, are difficult to resolve because the echo directly interferes with the propagating signal. On the other hand, given the strong electromagnetic attenuation of lung tissue, echo emanating from near organs is suppressed, and frequency-band tuning can be employed to range the depth of the investigation. Ultimately, this contribution shows how to employ and design UWB technology to localize deep pulmonary nodules through a minimally invasive approach.
\end{abstract}

Keywords: ultra-wideband; UWB; pulmonary nodules; lung cancer; localization; microwave

Supplementary Materials: The presentation file is available at https:/ /www.mdpi.com/article/10.3 390/I3S2021Dresden-10095/s1.

Informed Consent Statement: Not applicable. 